\title{
The Organizational Pattern of Theses for Graduates in B.A. in English Language Teaching
}

\author{
El Formato Organizacional de Tesis para Egresados de la Licenciatura en la \\ Enseñanza del Inglés
}

\author{
Elsa Y. Cruz-Maldonado ${ }^{a}$ Karime Cárdenas-Escobar ${ }^{b}$, Monserrat A. Hernández-Sarmiento ${ }^{c}$,

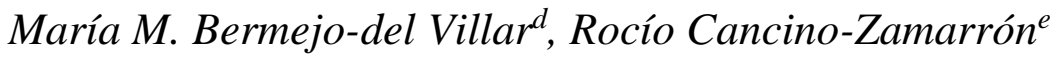

\begin{abstract}
:
Research is a fundamental factor for the development and improvement of any area of study. However, some English Language Teaching (ELT) undergraduate programs in Mexico usually fail to promote research in their schools. This is the case of the ELT the undergraduate program of the Escuela de Lenguas, Campus Tapachula in the Autonomous University of Chiapas (UNACH as for its initials in Spanish), where little is known by the school about the organizational pattern of the submitted theses by trainees. This is a descriptive study that seeks to reveal how these are structured in the Escuela de Lenguas, Campus Tapachula. This research was carried out by applying questionnaires to trainees, graduates, thesis-supervisors, and members of the reading committee and conducting a documentary analysis of the theses submitted from 2012 to 2019 to detail how they are structured. It was discovered that most of the theses are composed of four chapters, yet most of the participants agree on the theses of five chapters. According to the results obtained, two different outlines were designed varying in the number of chapters and the elements included in each one.
\end{abstract}

\section{Keywords:}

thesis, dissertation, outlines, components, thesis-supervisor

\section{Resumen:}

La investigación es un factor fundamental para desarrollar y mejorar cualquier área de estudio; sin embargo, los programas de licenciatura en la Enseñanza del Inglés (ELT) rara vez promocionan la investigación en sus propias escuelas. Este es el caso del programa de Licenciatura en la Enseñanza del Inglés de la Escuela de Lenguas Campus Tapachula, de la Universidad Autónoma de Chiapas (UNACH), donde poco se conoce sobre el formato organizacional de las tesis entregadas por los egresados. Este un estudio descriptivo que buscar revelar como las tesis se estructuran en la Escuela de Lenguas Campus Tapachula; y para lograrlo, se aplicaron cuestionarios a los estudiantes, graduados, supervisores de tesis, y miembros del Comité Revisor; luego se llevó a cabo un análisis documental de las tesis entregadas del 2012 al 2019 para detallar cómo están estructuradas. Se encontró que la mayoría de estas tesis se componen de cuatro capítulos, aun cuando la mayoría de los participantes concuerdan que las tesis deben tener cinco capítulos De acuerdo a los resultados obtenidos, se diseñaron dos tipos de formato diferentes variando el número de capítulos y los elementos incluidos en cada tipo.

\section{Palabras Clave:}

tesis, disertación, formatos, componentes, supervisor de tesis

\footnotetext{
${ }^{a}$ Elsa Y. Cruz Maldonado, Universidad Autónoma de Chiapas. ORCID: https://orcid.org/0000-0003-1044-2235 Email: yolanda.cruz@unach.mx bKarime Cárdenas Escobar, Universidad Autónoma de Chiapas ORCID: https://orcid.org/0000-0002-5990-4253 Email: karicares98@ gmail.com ${ }^{c}$ Monserrat A. Hernández Sarmiento, Universidad Autónoma de Chiapas ORCID: https://orcid.org/0000-0002-3501-4723 Email: monsehsarm@gmail.com ${ }^{\mathrm{d}}$ María M. Bermejo del Villar, Universidad Autónoma de Chiapas. ORCID: https://orcid.org/0000-0003-0301-8874 Email: maria.bermejo@unach.mx ${ }^{\mathrm{E}}$ Rocío Cancino Zamarrón, Universidad Autónoma de Chiapas. ORCID: https://orcid.org/0000-0003-1562-5049 Email: rocio.cancino@unach.mx
} 


\section{INTRODUCTION}

Throughout time, the teaching undergraduate programs, in general, have aimed to form professionals that are well instructed on the content of the subjects they intend to teach and, on the skills and tools needed to transmit their knowledge to students in an effective way. Moreover, nowadays, the research field has become an essential element in almost any area of study. Nevertheless, in the real life, the development of research skills has not been promoted by the Language School Tapachula due to the idea that as teachers there is no need to get involved in doing research projects, but as Griffee (2012) argues, if we, as teachers, never dare to do our proper investigations to solve problems in our field or answer our questions, no one else will do it and, "we will be doomed to keep repeating our experiences"' (p. 10).

Doing research is a fundamental factor for the development and improvement of any area of study. However, most of the English Language Teaching (ELT) undergraduate programs in Mexico seem to be not aware of this fact since the research made within the field of ELT has been described by some authors as incipient and not so productive (Ramirez, 2007; Tapia, 2013). According to a study conducted about the progress of ELT theses and dissertations in Mexico by Ramirez (2007), the poor production of ELT research projects can be explained because most of the ELT investigators lack enough expertise and knowledge about research given that there are just a few ELT teachers that do research and have had an appropriate preparation for that; besides, most of the research projects found in the study were theses written by undergraduate students, who can be categorized as novice researchers. Tapia (2013) argues that this problem can be attributed to the little attention that ELT undergraduate programs pay on developing the research competence within students since communicative and pedagogic competencies are usually considered the central ones.

During a preliminary revision of the theses submitted from 2004 to 2019, it was identified that the ELT undergraduate program of the Escuela de Lenguas, Campus IV, Universidad Autónoma de Chiapas (UNACH) is in the same situation described by Tapía (2003). It was found by the researchers that there is a low number of subjects that encourage trainees to do research with the purpose of obtaining the B.A. degree and a reduced number of teachers that are thesis supervisors which may be one of the reasons why the quantity of theses submitted is not very significant in relation to the number of trainees that have finished the undergraduate program; having that by October of 2018 only $11.8 \%$ of the total of graduated students had submitted a thesis. It is, therefore, important to increase the attention paid to encourage students to do research in the school, so trainees can rely on the previous knowledge and expertise regarding what a research process involves and the feeling of annoyance or dread can be diminished when thinking about doing research (Griffee, 2012).

Furthermore, in Escuela de Lenguas Campus Tapachula UNACH, few dissertations regarding the study of the development and progress of research in the school have been carried out, and with the exception of the project conducted by Moreno and Dominguez in 2007, there has not been another careful examination of the structure of the theses submitted by ELT students since then. Thus, the organizational structure of the theses produced during the last 15 years has largely gone unnoticed. As a consequence, little is known by the school about the organizational pattern of the submitted theses, and there is a wide gap about what graduates and thesis supervisors have been doing for years when researching. Therefore, an examination of the theses written in Escuela de Lenguas Campus Tapachula is needed in order to find out if ELT trainees have included the components that some authors (Bell, 2010; Griffee, 2012; Mackey \& Gass, 2005; Mauch \& Park, 2003; Paltridge \& Starfield, 2007) mention as essential within their handbooks and guides, which will help us to identify if the theses composed by ELT trainees accomplish the minimum requirements.

Moreover, it is also essential to delve into thesis supervisors', graduates', and trainees' perceptions about the structure of a dissertation. This comparison between their perceptions and the actual structure of theses presented at school may help comprehend better why they are composed as they are and the merge of the results may help to construct a complete outline of what elements a thesis should entail.

\section{ESCUELA DE LENGUAS CAMPUS TAPACHULA,} UNACH

This study is carried out in the ELT undergraduate program of the Escuela de Lenguas Campus Tapachula, UNACH. By January 2020, the institution employed 34 Mexican teachers and 320 students enrolled in the undergraduate program. The undergraduate program lasts around four years and a half, divided into nine terms in total. During this time, students take 55 subjects of which 36 are designed to be taught in English, 13 subjects in Spanish and the remaining 6 either in French or Italian. Furthermore, from these subjects, only four are intended to provide students with the basics of research: one introduces them to research writing in Spanish; two subjects introduce them to the research designs, methods, and instruments commonly used in the ELT research field, which are usually taken during the sixth and seventh terms of the undergraduate program; while the one that is taken in the last term (ninth) is 
centered around guiding trainees into the ways of obtaining the college degree, especially in structuring a research proposal that may be developed into a thesis.

In the official webpage of Escuela de Lenguas Campus Tapachula, UNACH (2018), six different options to obtain the college degree in ELT were found. One of them is Reconocimiento al Merito Academico (academic recognition) in which students having an overall grade average of 9.5 or above without taking an extraordinary exam during their studies can apply for that. Excelencia academica (academic excellence) is an oral exam of six different subjects from the curriculum of the undergraduate program, chosen by the jury of professors that evaluates the candidate, who needs a grade point average of 9.0 without taking an extraordinary exam during their studies. Examen profesional mediante Tesis (professional evaluation through thesis) requires trainees to carry out a thesis project about a pertinent issue concerning the ELT field, which can be written individually or in groups with a maximum of 3 candidates. The thesis supervisor-in-charge revises and corrects the project during its creation and the professors that belong to the reading committee evaluate the work of the thesis quality at the end. Evaluación por créditos de Posgrados (evaluation through postgraduate credits) is for the candidates who decide to study the master's degree in their field and who will need to obtain and pass $50 \%$ of the credits of the curriculum that they are studying. Evaluación por Seminario de Titulación (evaluation through a seminar) for obtaining a degree involves students taking 125 hours of extra courses related to research. The group is formed with a minimum of twenty students. The last way to graduate from the Universidad Autónoma de Chiapas is the Examen General para el Egreso de la Licenciatura (EGEL) (general exam for the undergraduate), which is administered by the Centro Nacional de Evaluación para la Educación Superior, A. C. (CENEVAL).

In this undergraduate program, the ELT students increase their ability to communicate in English but more specifically, it provides them with the necessary tools and abilities to be effective English teachers. Although it gives them the necessary competencies for teaching the language, the school could allow more opportunities for students to be trained in developing research competencies not only at the end of the program, but also throughout the career, so they do not feel intimidated when writing their theses.

\section{STATEMENT OF THE RESEARCH PROBLEM}

The students of the ELT undergraduate program of the Escuela de Lenguas Campus Tapachula, UNACH have the opportunity to get their college degree by writing and submitting a thesis. According to Moreno and Dominguez (2007), who analyzed research papers and dissertations produced in the Escuela de Lenguas Campus Tapachula UNACH, it was found that up to
2005 there were only four theses written by graduated students of the undergraduate program at Tapachula; moreover, Moreno and Dominguez (2007) stated that the field of study of those dissertations had not been explored thoroughly nor had they been studied rigorously since the topics had not been well defined. Since that study, there has not been another one that examines the recently presented theses that each year are submitted by the few students that choose it as a way to get their college degree.

Due to the lack of attention that has been paid to the newly submitted theses, when doing a preliminary analysis of the ELT graduates' dissertations, it was observed that the pattern of the organization was very diverse and they did not follow a specific structure. It can be accepted that the structure of a thesis may vary according to many factors like the research perspective and purpose, the supervisor's beliefs and advice, the public to which it is addressed, the time in which it was written, the requirements asked by the academic discipline or institution, among others (Prior, 1995 as cited in Paltridge \& Starfield, 2007): In spite of these variations, Paltridge \& Starfield (2007) argue that students need to know the usual structures that theses follow "so they can make choices from the range of patterns of textual organization that is typically associated with instances of the particular genre." (p. 67)

In this way, the research subject involving specifically the conduction of a theses is taken until the 9th term and the institutional guidelines provided by the school with the four chapters to include in the dissertation is shared with trainees until they are going to register their research proposal. Meanwhile, what trainees do with their research project depends on the points of view from their thesis-supervisor and the teachers in charge of the research subjects, which sometimes can be different opinions, making the process of writing a thesis even more challenging. Furthermore, another problem that emerges is that when the thesis is prepared to be read and examined by members of the reading committee, their different perceptions do not agree on how the work is presented, causing unexpected changes in terms of how the academic paper is organized.

In the light of the above mentioned statements, this project emerges from the need of delving into the theses submitted by ELT graduates, as well as into trainees, graduates, thesis supervisors' and members of the reading committee perceptions about how they think a thesis is composed with the purpose of making a comparison between the data gathered from the questionnaires and the repertory grid technique which outlines the structure of a dissertation proposed by handbooks, guides, and books. This research does not attempt to judge nor to focus on the content of the theses submitted, but to describe how they are usually structured. 
This study attempts to answer the following questions: What structure do submitted theses in the ELT program usually follow? And what components do ELT thesis supervisors, members of the reading committee, graduate, and trainees consider a thesis should entail? In order to answer these questions, this study will try to accomplish the following general purpose:

- To describe the structure of the theses written by the ELT graduates according to an analysis of these academic papers and the perceptions of trainees, graduates, thesis supervisors and members of the reading committee.

Moreover, to accomplish this, the next specific purposes will be followed:

- To examine the structure of the theses written in Escuela de Lenguas Campus Tapachula UNACH by the ELT graduates

- To discover to which extent, they accomplish what the literature consulted have mentioned in their handbooks and guides about the components of a thesis.

- To identify the usual outline of the elements of a thesis that supervisors and members of the reading committee often consider important when assessing ELT undergraduate trainees.

\section{LITERATURE REVIEW}

According to Paltridge (2002), there are very few studies that have examined the structure and organization of theses as a whole, while there are many studies that have focused on specific sections or chapters. Paltridge and Starfield (2007) quote Atkinson (1997) to explain why this may occur. Some of the reasons they mention are related to the difficulty to have unlimited access to the dissertations in the university libraries, the extension of these works, plus the quantity that can be analyzed by researchers; these three obstacles have been also faced during the analysis of theses during this research. Furthermore, Paltridge and Starfield (2007) explain that it is a bit problematic to carry out this type of analysis since this type of academic papers form part of a "complex genre" (Paltridge, 2013, p. 350) and its composition will depend on many factors, so it cannot be always expected to find the same structure on each thesis.

On the other hand, Wang (2016) states that every time a message is going to be delivered, it is done with a purpose, and some moves and steps are followed in order to communicate it adequately; thus, a specific structure is adopted, which is determined by what, where, when, to whom and how we want to express something, or in other words, the genre to which the written or spoken discourse belongs to. Therefore, either thesis is regarded as a genre by itself or a type of text within the academic genre. Its structure consists of certain elements that cannot be omitted, whereas others may be optional, and as some authors (Paltridge, 2007; Tardy \& Swales, 2009; Wang, 2016) state, this structure works as guidance of which the researchers should have an idea, so they can make adequate choices.

From the studies carried out by Komba (2015), Paltridge (2002), and Ramirez (2007), it was drawn that although the research projects do analyze the thesis discourse structure, the approach and purpose for which they do it varies significantly as it will be exposed. To begin with, Paltridge (2002) carried out an important study comparing the advice given by guides and handbooks about thesis writing and 30 dissertations written by postgraduates (masters and doctorate) of different study areas of an Australian University. This study was carried out not only to find out if the dissertations followed the published advice but also to expose the lacks of literature about thesis writing by demonstrating that they can be classified into four major categories, each one consisting of different elements arranged in distinctive ways.

Furthermore, the data gathered in this study serves as a baseline for future investigations and for highlighting the importance of evaluating the research projects to identify the inconsistencies and to propose possible solutions to develop theses of better quality. Besides, this study helps to strengthen the need to start producing guides and handbooks about dissertation writing based on real examples and to reinforce the belief of teaching research through the analysis of them. On the other hand, many distinct study fields were covered and few theses were examined, making this study less representative of the structure and organization of the research work. Additionally, as it was mentioned before, advice about teaching research and thesis writing is given by this study despite the fact that it is only documentary research that did not take into account other sources of data, such as the thesis supervisor or those who teach research classes, participants that would have helped shed light on their teaching practices and perceptions about this topic.

In Mexico, a large study similar to Paltridge's was coordinated by Ramirez in 2007, with the help of a group of 37 professors/researchers who gathered information related to dissertations submitted in the foreign language teaching area during 2000 and 2005. They worked with 15 states of Mexico and revised 494 research projects taking into consideration only 264 because the rest did not accomplish the established requirements that Ramirez (2007) asked for to be considered investigations. The fact that only $53 \%$ of the total number of the dissertations reviewed in the study achieved the minimum specifications for being taken into account was something worrying. Therefore, that discovery strengthened the need to keep a record of what has been investigated in the ELT field of the last years in Mexico, and to inform students as well as teachers of the improvements to be made in this field. Although it was a large study, the researchers employed the same registration form provided by Consejo Mexicano de Investigación Educativa (COMIE), making the data gathering 
consistent. However, the analysis did not have specific criteria to be accomplished, giving the researchers the freedom to choose the depth of their study and the decision of what methodologies to implement, how to present the results, among other criteria. This is something that made the study very diverse concerning the range of results obtained, which for some states were based only on the documentary analysis of the research projects, whereas, in others, interviews were applied to teachers, heads of departments, and other administrative staff to find a possible explanation to justify why these were written in the way they were. Something remarkable in this investigation is that it gives an insight into what investigations in EFL in Chiapas were from 2000 to 2005 , which is the only study of this type done in UNACH until now; thus, a reason why it is necessary to carry out a new one. Finally, the results given by this study are very alarming, both nationally and regionally, since they demonstrate that the research field in foreign language learning is still developing and it has many deficiencies.

On the other hand, it is worth mentioning a more recent study about the thesis discourse structure carried out in Tanzania by Komba (2015), which is a qualitative research project that analyzed 103 dissertations by employing a documentary research instrument similar to the one designed for the current study. However, this study employed the instrument to point out the challenges faced by postgraduate students when writing each chapter of the theses, in contrast to the current research that grasps a more structural analysis focusing mainly on describing how dissertations are composed in ELT by examining them with what the published literature proposes. Thus, the investigation by Komba (2015) barely grasps the literature basis on which the instrument is based. What is remarkable about this study is that it highlighted important deficiencies in the academic field that explain why dissertations submitted may be "substandard" (Komba, 2015, p. 79). Some of the discoveries made through the corresponding analysis were that most of the weaknesses found in each chapter are rooted in ineffective training concerning research and academic writing.

As it was exemplified in the above paragraphs, even though the studies had different purposes and approaches for carrying out the analysis, all of them shared some similarities. First of all, most of the institutions, whose research works were examined in the investigations, received observations related to the improvement of theses to produce research works that accomplish the required standards. Secondly, all of those studies demand institutions to put more emphasis on research courses, as well as to do a re-analysis and modification of the training courses of research that are not only for ESL/novice researchers but also for the trainers and teachers related to the research committee of institutions. Thirdly, by reading these studies, it is evident that examining the discourse structure of a thesis is needed in institutions where investigations are being carried out so that the weaknesses and gaps that have been overlooked can be identified and treated properly. Finally, none of these studies took into account trainees' previous ideas about what a thesis project could be, so that a wider view of the effectiveness of training research courses could be obtained, and data-driven conclusions can be drawn.

\section{Studies about the Thesis Supervisors Role}

Some studies have taken place. However, most of them are focused on supervisors and supervisees. Most of them have explored certain aspects such as perceptions about their mutual relationship, the difficulties, and obstacles they face during the process of research, as well as the quantity and the quality of influence the supervisor has on the writer. Remarkably, when it comes to thesis structure and organization few studies have been conducted using supervisors and supervisees as the source of data. Furthermore, it was found that the studies about thesis research usually disregard issues concerning undergraduate research, whereas they commonly concentrate on postgraduate issues.

Nevertheless, as both types of studies share many similarities regarding the duties the supervisors execute as well as the problems they face, studies carried out at the postgraduate level were also taken into account. Last but not least, it was hard to find studies about thesis research in the ELT field specifically since most of the studies are usually conducted in different areas of studies, and they commonly take as participants supervisors that deal with L2 writers. It is, therefore, essential conducting research that takes into consideration supervisors' perceptions of the thesis structure at the undergraduate level in the ELT field.

The role of supervisors has been defined by Tapia (2013) as a vital influence in the trainee since they are the ones in charge of giving advice when trainees have difficulties with the research design, data collection, or data analysis. Tapia (2013) adds that supervisors also help to develop and complete the research project intended in the time and manner predetermined by the institution. In addition, Bitchener, Basturkmen and East (2010) see a peer-to-peer relationship between the trainee and supervisor in a way that the supervisor is the most knowledgeable peer guiding the trainee to become an autonomous researcher. Consequently, supervisors are the voice of experienced researchers whose work is to solve students' doubts and problems and whose help is totally necessary to shape their thesis projects as it is required.

Mastery of the structure and organization is crucial for both supervisor and supervisee since the first one has to teach it and help the latter submit a thesis project that accomplishes the minimum requirements. Based on a survey conducted by 
Donnelly, Dallat, and Fitzmaurice (2013) on the views of supervisors in undergraduate programs, they found out that advising on how to structure the research work was one of the first things to do and one of the primary aspects of supervising. Moreover, Bitchener et al. (2010) in their research carried out about the focus of feedback given by the supervisors, an important element on which they reported a lot of attention was paid on the specific parts of the thesis and their specific components. In this way, some supervisors indicated that introducing and giving students specifications on how to structure their dissertation just at the beginning was effective as it avoided the need to provide feedback in a written way later on; on the other hand, some supervisors argued clearly that this did not imply that further feedback about the structure and function of each part was not necessary as they emphasized that it was something to be repeated various times to students. In a more specific study on this conducted by Peng (2018) in a Chinese university with supervisors of L2 postgraduate students, it was found out that thesis drafts had to be examined repeatedly and severely in regard to not only to linguistic but also generic mistakes. Peng's study (2018) concludes that these deficiencies are rooted in students' inefficient education concerning research.

Students' lack of research abilities and language proficiency are often reported by the supervisors as central issues, conceived as a negative impact on the thesis quality. For instance, Donnelly, et al. (2013) revealed that supervisors of undergraduate students encounter regularly with students who are not well prepared academically to develop a research project since many do not even master the basics of fundamental skills like writing, and reading, nor much less do they possess sufficient critical thinking skills when processing information. This study also pointed out that supervisors face some special difficulties with L2 writers that are related to their low proficiency level in the target language.

Peng (2018), in spite of having worked with postgraduate students, agrees with Donnelly, et al. (2013) since the supervisors in both studies share the same concerns regarding students' poor reading and writing skills, as well as their frequent linguistic mistakes in their thesis projects. Peng (2018) also adds that supervisors report having students whose research competence has not been developed as they cannot connect easily their research project with the literature revised, and they still need to work over some abilities like "comprehension, problem-finding, problem-solving, and generalizing”' (p.101). Moreover, Peng (2018) stresses that the lack of knowledge of the specific features of the dissertation as a genre is a significant problem with which supervisors are highly troubled. It was therefore reported that the literature review and discussion parts are the most influenced components since supervisees usually mistake their function and how they should be constituted.
However, whether or not the thesis projects reach the standards will not only rely on the supervisors and supervisees, but they will be also determined by some external factors. Peng's study (2018) states some of them, arguing that students may not count on the abilities and knowledge required for developing an appropriate thesis due to "limited access to academic resources, inappropriate schedules and ineffective curricula" (p. 96), as well as an absence of training and exercising some critical reading and academic writing skills, and familiarizing students with what research papers involve. On the other hand, Donnelly, et al. (2013) observe that supervisors do not have access to courses that instruct them about the supervisory practice, nor much less that provide them with strategies to improve their guidance about thesis structure. Lastly, Donnelly, et al. (2013) and Tapia (2013) agree on the fact that there is insufficient research concerning the undergraduate supervisory practice so space for reflection and discussion of the techniques and strategies implemented can be opened.

In relation to these external struggles and from the results of the studies carried out, some possible solutions were drawn. Firstly, Peng (2018) strongly advises implementing more courses of EAP related to improving the writing skills and introducing students step by step to the parts of a thesis project. Next, Bitchener et al. (2010) point out how essential it is for supervisors to provide explicit and reiterated advice on how it is best to structure the content of a thesis. Finally, concerning research done in dissertation genre analysis, conducting more studies that estimate the problems that may arise when structuring the thesis from the point of view of the supervisors is suggested (Peng, 2018). To sum up, when structuring the dissertation project supervisors have a vital influence on the result of adequate research work, hence supervisors must possess a clear foundation about it and can introduce and guide students appropriately to this new genre, taking into consideration the fact that students are a novice in the research area and they do not probably have the abilities to undertake a task like this.

\section{Studies about Students's Perceptions}

As it was previously stated, there are a few investigations on supervisors' perceptions of the thesis structure, yet when it comes to students the panorama changes. In recent years, this kind of research based on graduate and undergraduate students' perceptions (the latter less explored than the former) have been investigated and have received attention in the EAP field, which has occurred since the results have shed light on what students find the easiest and the most difficult when writing research papers. Therefore, research along this line has become a significant source of information to improve supervisory practice, research, and academic writing courses. Since it brings up valuable results and recommendations, it has become 
essential to keep investigating students' perceptions of the thesis structure.

First of all, from the literature consulted, it was discovered that how students deal with the structure of a thesis varies significantly, having that some may perceive it problematic in distinctive ways since the components they find as simple or complex may vary slightly. For instance, Shaw (1991) interviewed 22 non-native postgraduate students about their practices when writing a thesis and one of the issues was about how they structured their project; students usually have a hard time when composing the introduction and the discussion parts. The interviewees in this study argued that these parts are complicated as the requirements of each one and their organization cannot be easily drawn from other dissertations.

Furthermore, Shaw (1991) adds that the literature review may be misunderstood as not difficult for those who ignore what its demands and function are. On the other hand, Singh (2015) administered a questionnaire to 131 non-native postgraduate students from different disciplines and stated that the literature review, results, and methodology parts were the most complex components, while the introduction is not perceived as a problem. In addition, a more profound study about this was conducted by Gomez (2014) in Colombian universities, from which supervisors, students carrying out their dissertation projects, and graduates that had already finished their dissertations were involved. The results obtained from students and graduates were different concerning the most troubling components. For instance, the students that had not finished their thesis project considered the literature review as the hardest part, whereas the introduction and methodology did not represent a big challenge to them.

On the contrary, graduates faced a greater challenge writing the data analysis than the literature review, and also they mentioned the introduction as the third most difficult part. In contrast to Singh (2015), Gomez (2014) outlines some of the reasons why students and graduates may encounter difficulties when writing the specific parts of the thesis, generalizing that it is mainly due to the lack of good formation and explicit instruction about the requirements and organization of each section. Lastly, Ho (2013) and Yeh (2010), who conducted research with participants from the first year of master degree programs in Taiwan, revealed that the most troubling component is the literature review. Something remarkable about Yeh (2010) is that she reported her participants did not point out the structure as a hurdle, yet she emphasizes that they did not comprehend entirely the requirements of each component. In conclusion, according to these findings, the literature review is the only component on which all authors agree to be complicated, a finding that was also found in the studies that have investigated supervisors' perceptions of this matter.
Even though not all studies described the reasons why some parts may be more complex than others, Gomez, 2014; Ho, 2013; Shaw, 1991; Yeh, 2010 did state what strategies students implement to facilitate the "appropriation of the genre", (Gomez, 2014, p. 324). A strategy that they commonly report is to seek advice from other thesis projects; for instance, Gomez (2014) and Yeh (2010) argued that students usually examine theses of their field or related to their topic to reproduce the structure, and Shaw (1991) stated that they usually review from four to five dissertations until they find one pattern that accommodates to their topic. Gomez (2014) also added that students often consult issues concerning the structure with their peers, whereas Yeh (2010) reported that students relied greatly on their supervisors' advice and feedback on the structure.

Concerning supervisors, Gomez (2014) also exposed some strategies that they applied and that students found useful like giving a list with the specific components and subcomponents at the beginning of the thesis development, referring students to thesis projects that could be useful for their topic and research line, as well as giving explicit information about what to include in each chapter. Moreover, other authors exposed strategies that students implement to improve their performance in specific components, mainly about literature review; however, they were more related to solving particular academic writing and linguistic problems than generic ones.

From those studies, it was found that although writing a thesis may be a task of which universities and students are aware of doing it at a certain point during their studies, the majority of writers usually possess merely theoretical knowledge and little practical expertise in conducting research. Furthermore, Ho (2013), Singh (2015), and Yeh (2010) suggest that research writing workshops and courses should be considerably emphasized during the academic development of students; besides, Singh (2015) even proposes the creation of learning support centers where more skilled researchers can share their knowledge and help introduce novice researchers into the research discipline. It is also recommended by Ho (2013) and Yeh (2010), who demand the involvement of more personnel in students' training of research abilities. Consequently, Gomez (2014) advises that the thesis process should be present within the syllabus of other subjects. Last but not least, Shaw (1991) makes some precise recommendations on how EAP courses should deal with students' adjustment to a new genre, from which socialization of knowledge is an essential part as well since he proposes academic groups as a tool to discuss issues related to the genre of theses and dissertations.

Although these studies bring up useful findings and recommendations, none of them focuses on undergraduate programs, nor do they take into account students' perceptions before undertaking a thesis. Carrying out a research under these conditions would lead to significant insights into the efficacy of 
the research courses previously taken, and to determine, in the specific case of the current study, if the courses allow students to get familiarized with the structure of a thesis. Moreover, with the exception of Gomez (2014), much of the research done in this line has only relied on participants' perceptions and has overlooked the documental analysis of dissertation projects.

\section{Thesis and Dissertation Writing}

Carrying out a research project is often seen as the final outcome of accomplishing a degree, which can be either within an undergraduate, master or Ph.D. program; it is certainly not the only option that students have nowadays, but it is definitely the most fruitful and challenging above all since it involves the "student's ability to carry out scholarly independent work consistently and in-depth" (Mauch \& Park, 2003, p. 24). Although the completion of a thesis is such an essential part of any academic or professional program, there are not so many books whose main aim is to guide students, supervisors and institutions throughout the research process in the submission of a thesis (Paltridge \& Starfield, 2007). The literature consulted in order to establish the format of a standard thesis that this study will employ was Bell (2010), Griffee (2012), Mackey and Gass (2005), Mauch and Park (2003) and Paltridge and Starfield (2007). During the reading of these books, guides, and handbooks, the different usage of the terms "thesis" and "dissertation", was identified, as well as the diverse ways in which they list and organize the main elements of a thesis, was compared, matters that will be discussed in the following sections.

\section{Definition of Thesis and Dissertation}

The distinction between thesis and dissertation can be very confusing since their definition gets to be similar as they share many characteristics. According to the literature consulted, it was found that the terms can be used differently depending on which degree of a study program is referred to but mainly from which region it is done. However, it is fundamental to clarify that many of the books consulted only focus on giving advice on how to carry out a research project in general, and lack an emphasis on theses in particular. This was the case with Griffee (2012) who barely mentions this terminology all (68) throughout his book; Bell (2010) and Mackey and Gass (2005) who do use both terms at the same time, do not explicitly mention any distinction between them, but just use them accompanied by the study program degree of which they refer to, from which conclusions can be drawn. While Bell (2010) uses dissertation when talking about undergraduate programs and uses thesis for postgraduate programs, Mackey and Gass (2005) use the terms the opposite way.

On the other hand, Mauch and Park (2003) and Paltridge and Starfield (2007) clarify the usage of both terms. Paltridge and
Starfield (2007) refer to Paltridge (2002) in order to gain a wider explanation about the usage of both concepts, where it can be found that the selection of writing either thesis or dissertation may vary according to the place from which the study program is being accomplished. For example, Paltridge (2002) states that for British institutions in undergraduate and master programs students are required to submit a dissertation, while for American institutions a dissertation is only submitted in Ph.D. programs.

In addition, Mauch and Park (2003), who follow the American model, define a thesis as "the product of a scholarly and professional study at the honors or the master's degree level.', (p. 9), and a dissertation as the study carried out at a doctorate level, thus it is considered to be a more mature work, whose subject of study is explored in a more rigorous, extended, and independent way than a thesis. As it can be sought, the only difference between these two terms is how deep or precise the results obtained are and whether it is a thesis or a dissertation is only determined by the specific requirements that the institution asks for. This is something that it is not clear at Escuela de Lenguas Campus Tapachula UNACH, so this study agrees with Paltridge (2002) on the fact that "as much of what can be said about a thesis also applies to a dissertation" (p. 125), having as a consequence that both concepts will be used at the same time similarly to Mauch and Park (2003) who abbreviate the terms as thesis. To sum up, the thesis could be defined as "the culmination of a multitude of experiences through which students are socialized into the values and the ways of doing that are conventional to a given research community', (Thompson, 2013, p. 290).

\section{Choice of Literature}

The books, handbooks, and guides selected were published within the years of 2003 and 2012. Some of them are edited or updated versions of their originals. They were chosen since they provide their own advice on which elements to include in a thesis and how they should be organized, approaching in their own manner the process of conducting a thesis and putting more emphasis on some sections or aspects than in others. This diversity obtained by the literature provided the study valuable insights about the aspects to be taken into account when getting involved in a research project.

In An Introduction to Second Language Research Methods: Design and Data, Griffee (2012) intends to make a simple guide for novice researchers involved in the teaching field. Through very clear examples, he gives explicit advice in $v$ regard to what to do and what should be covered in a thesis, but as the title of his book implies, his aim is to provide broad explanations about the variety of research designs and research methods for novice researchers. It is, therefore, valuable since it provides very 
detailed and precise instructions on what to include in the methodology chapter.

Bell's (2010) guide Doing Your Research Project approaches the process of a thesis from giving advice about some research habits and techniques that should be taken into account since the very first stages of developing a study. Moreover, it specifies the steps to follow when choosing a research design, and preparing the research instruments, describing in-depth each situation. Her guide does not have as a priority directing the researcher throughout the organizational structure of a thesis since it dedicates only one section in the final part of her book to describe in a very short and superficial way the elements that a dissertation comprises. Consequently, she only provided bare details that were found in almost all the rest of the literature consulted.

Paltridge and Starfield's (2007) handbook Thesis and Dissertation Writing in a Second Language: A Handbook for Supervisors was the most complete and useful source for this study since it dedicated one chapter per each section of a traditional thesis. Very detailed descriptions were given of all the essential subsections that each chapter should have. Furthermore, as it is addressed to second-language speakers, with the help of examples from real theses (that come from different fields but mainly related to ESP), it provides advice on what the common grammatical structures, phrases, and lexicon the researcher should use. Mackey and Gass' (2005) book Second Language Research: Methodology and Design makes emphasis on the development of chapter three about methodology and four about results of a thesis, providing in a very descriptive way what the research methods and research designs are about (particularly the quantitative ones), as well as largely explaining what research instruments can be implemented depending on the research questions and design, and how the data can be analyzed. Although its focus is on methodology, it has a chapter that describes each part of a dissertation in a brief way, providing useful information about what to tackle with within the methods and discussion sections.

Finally, Mauch and Park's (2003) Guide to the Successful Thesis and Dissertation is not focused on second language research and it is the one that tackles the thesis process in the most general way. The book provides advice mainly on external factors and situations to be taken into account like the authorities to which the researcher has to respond to and how to deal with them (supervisors and committee), the complete process of developing and presenting a research proposal, and even some things to consider about the defense of the study. Although it does not thoroughly describe what to do specifically in each section, it does provide some explanation of certain elements. Moreover, it includes a chapter where it gives the outline of a thesis, and it clearly outlines the elements to consider for each chapter, having a strong emphasis on the conclusions chapter.

\section{Overall Shape of a Thesis}

As it was stated from the beginning of this section, each author has its proper manner of approaching the thesis structure and therefore, a section or sections on which they pay more attention to; nevertheless, they all attempt to include all the elements they consider essential. Some elements and sections are not very often assigned or divided similarly; this diversity strengthens the fact that it cannot be established a standard form that applies for each research paper since the chapters will be delimited and entitled according to the specific characteristics and requirements of the study (Paltridge, 2002).

To begin with, Griffee (2012) in his "Introduction to Second Language Research Methods: Design and Data", the format described is comprised by introduction, participants, materials, procedures, analysis, results, and discussion; as argued before, Griffee (2012) puts a strong emphasis on the methodology, thus he divides it as three separate parts, giving very specific instructions on what to write in each one of them. By contrast, Griffee (2012) provides reduced information in regard to the introduction and discussion sections and does not put the literature review as an independent one, but as a part of the introduction. Something on which Mackey and Gass (2005) agree with, since they only present the following four chapters: introduction (where a literature review is found), methods, results, and discussion/conclusion. Hence, as the central focus of Mackey and Gass (2005) is on methodology, their description of the elements concerning the methods and discussion/conclusion section is done in an exhaustive way.

In spite of the little amount of attention that Bell (2010) dedicates to the arrangement of the elements in a thesis, she does mention the fundamental sections with the following titles: Aims and purpose of the study, review of the literature, methods of data collection, statement of results, analysis and discussion, summary and conclusions. She presents the six sections with very basic indications of what each one should contain, matching with usual characteristics found in the rest of the literature chosen. For instance, the first one, although it is named specifically as the aims and purpose of the study, includes the essential characteristics given by other authors in regard to the introduction part.

In A Guide to the Successful Thesis and Dissertation by Mauch and Park (2003), they also mention six sections, of which the two first sections are divided with different criteria as they present the introduction and the problem as two separate parts. The rest of the sections, in spite of having a different title, do coincide more in the way Bell (2010) and Paltridge and Starfield (2012) have organized the sections, with the review of literature, 
research procedures, findings, and conclusions and implications. It is understandable why Mauch and Park (2003) put aside the problem as an independent section since they add more elements to be taken into account when describing the problem. They also make a strong emphasis on what to include in the review of the literature and conclusions and implications parts.

Paltridge and Starfield (2007) establish a thesis structure based on delimited chapters, determining five main chapters for what they call a "traditional thesis" (p. 67), which consists of the introduction, literature review, methodology, results, discussion and conclusions. Since the same importance was given to each section and the description was done in a general way, entitling all the essential elements without going too much into particularities, the structure given by Paltridge and Starfield (2007) served as the frame from which the rest of the standard formats proposed by the authors were adapted to. Thus, the thesis format that will be followed in this study consists of the five sections mentioned by Paltridge and Starfield (2007); however, each section is comprised of elements and characteristics on which at least three authors coincided.

\section{Results of Theses Analysis in Escuela de Lenguas Campus Tapachula, Unach}

Of the 44 theses submitted between 2012 and 2019 in Escuela de Lenguas Campus Tapachula, UNACH, only 20 were analyzed as 24 did not accomplish the requisites for being social service or three-chapter projects. it was found out that very few theses encompass five chapters (labelled as group a theses), while there are various entailing four chapters (labelled as group b theses) as recommended by the institutional guidelines. in contrast, the perceptions collected in the questionnaires revealed that most of the respondents $(88 \%)$ agreed on the idea of five chapters in a thesis.

Concerning the division made between the dissertations, it helped to identify that the theses from group a accomplished more elements and had more completed chapters as the scope given to some of the sections was wider than in the ones from group b. moreover, this evaluation helped to distinguish between the elements that are mandatory and those that can be optional from the repertory grid technique.

Regarding the results from the questionnaires, they served to approve the elements that had been placed as mandatory or optional. furthermore, most of the sentences in section three received scores of $4 \mathrm{~s}$ and $5 \mathrm{~s}$ by most of the respondents, which made a contrast with the results obtained from the repertory grid technique. Finally, from the three groups of participants, the trainees were the ones that showed more uncertainty and provided more varied answers; the teachers were the ones that provided more useful feedback.

Both research questions in this project attempted to find out the structure of theses in the b.a. in english language teaching at the escuela de lenguas campus tapachula, unach; therefore, the results from both will be commented on at the same time, outlining the structure found through the analysis.

To begin with, the introduction was one of the steadiest sections in both the theses analyzed. The results from the questionnaires were also perceived by the graduates as a non-problematic section, which matches with Gomez's (2014) findings where the introduction is perceived as an easy part. However, in three of the theses from group B some essential elements were omitted and methodology was usually found in this first section, while the most omitted elements in both groups were delimitations and limitations of the study, which is a fundamental element that prepares the researcher to stick to a plan with certain boundaries and to design solutions to possible obstacles. The other most dismissed element was key terms, which relies on the consideration of the researcher.

Concerning the literature review, the results from the questionnaires and the repertory grid technique did not coincide on one element: studies related to the issue under investigation. While in the analysis of the theses, very few of them presented studies, in the questionnaires, most of the respondents agreed to include them. Incomplete literature reviews may be due to the fact that it is usually the most difficult for the majority of novice researchers. In relation to this matter, Peng (2018) and Shaw (1991) state that the function of the literature review is usually mistaken or not comprehended at all. Furthermore, Peng (2018) argues that the previous academic background determines a big deal in the success of this section.

In the methodology section, a high level of agreement was obtained. However, this was not reflected on the theses analyzed as very often not all of the elements were found in them. Methodology is usually perceived as one of the most difficult after literature review not only by the graduates but also by the participants of other studies consulted, therefore it is understandable why many inconsistencies are found. Moreover, Bitchener et al. (2010), and Peng (2018) recommend that repeated feedback is needed as well as severe examinations, thus trainees doing research for the first time can structure better their work, as they are novices in the community of research (Bitchener et al, 2010; Thompson, 2013). However, this is not always possible in Mexican universities, as Ramirez (2007) points out that the working conditions of the teachers that are supervisors make it difficult to give a space for research not only in terms of time but also in terms of other resources that could benefit like budget and school facilities.

Going back to methodology, setting and population are the most troubling sections as they do not have a specific place in the theses examined. Respondents agreed with including it in chapter 3, while few added that they would put them in chapter 1. Therefore, according to the authors consulted and the results obtained, population is suggested to be placed in chapter 3, usually included in this part in the theses from both groups; in relation to setting, it has been given the option to place it 
whether in chapter 1 or chapter 3, depending on the needs of the study. If a detailed explanation of the setting is needed again for the understanding of the methodology chapter, it could be done in both parts.

Results/findings were perceived to be one of the most affected sections due to the narrow scope given in the theses of four chapters as no space was left in some for putting charts, tables, and figures in the description of the results/findings, something that does not alter the research, but it does help the researcher to emphasize certain issues to the reader. in this way, the same happened with the restatement of the problem, research design, and data analysis method, which according to the authors consulted, this part should begin with these elements.

However, results obtained through the questionnaires and repertory grid technique point out the contrary, as they were one of the least elements to be found in the theses, and not many participants agreed, having that some of them even argued that it was too repetitive. therefore, taking into account the extension given to this section in dissertations of four chapters and that the addition of these elements is just a tool to help the reader, including them is totally optional. Finally, the initial way of presenting the results proposed by the repertory grid technique was according to the research questions. However, as it was later found out, most of the theses examined presented other ways of doing it, which are also recommended by some of the respondents (mostly teachers) and some of the authors (Mauch \& Park, 2003; Paltridge \& Starfield, 2007).

In both groups of the theses analyzed, it was discovered that the discussion and conclusions part was mostly composed of the main idea of the study, summary of the findings, and impact of the study in terms of what was learned, (109) something which the respondents agreed on. On the other hand, limitations that may affect the validity or generalizability of the results/findings and implications for future research were barely found in the theses from both groups. The presence of both has been suggested by Mackey and Gass (2005) as a source of ideas for other researches, who in this case are trainees wanting to conduct a thesis as a way to get their college degree. hence, having these suggestions given by graduates in previous theses may facilitate trainees the choice of a topic and the way of studying it, widening and improving the study of specific research branches of language teaching in the ELT program.

\section{Conclusion}

Nowadays, doing research is an essential factor for the development and improvement of education. Unfortunately, as Ramirez (2007) and Tapia (2013) argue, research in the area of language teaching in Mexico has still so much to explore and this may be due to a set of constraints that do not facilitate the involvement of teachers and trainees into this practice. Even though these limitations may be diverse in origin, strength, and type, Mexican researchers like Ramirez and the community that has been participating in his studies about the status of foreign language teaching research in the country $(2007,2013)$ have attempted to identify these boundaries and weaknesses and to seek out solutions to overcome them.

In this case, the current study described some of the thesis projects' structure in the ELT program, which gave as a result, two outlines with the essential components of a thesis, one trying to follow the institutional guidelines and the other one following the authors' advice. This was made with the aim of facilitating the structuring and organization of a thesis project for trainees being initiated into research. Simultaneously it attempted to encourage the community of the ELT program to relate trainees to thesis and small research projects so the idea of doing research does not frighten them so much. Nonetheless, it is known that this is not even close to being a solution for the lack of an organizational pattern for thesis writing nor is it for the low number of dissertation projects submitted in the ELT program since many other factors must be taken into consideration for proper study.

\section{REFERENCES}

[1] Bell, J. (2010). Doing your research project (fifth edition). U.K: Open University Press. Retrieved from https://www.academia.edu/16705868/Judith_Bell_Doing_Your_Resea rch_Project_Mc_Graw_Hill_Education_2010?auto=download

[2] Bitchener, J., Basturkmen, H., \& East, M. (2010). The Focus of Supervisor Written Feedback to Thesis/Dissertation Students. International Journal of English Studies, 10(2), 79-97. https://doi.org/10.6018/ijes/2010/2/119201

[3] Bowen, G. A. (2009). Document analysis as a qualitative research method. Qualitative Research Journal, 9 (2), 27-40. Retreived from https://doi.org/10.3316/QRJ0902027.

[4] Cruz, E., Cancino, R., Bermejo, M., Girón, A., (2017). Towards an Integrated Approach in Esp: A Mexican Needs Analysis Study. Retrieved from
from https://www.lenguastap.unach.mx/images/publicaciones/TOWARDSAN-INTEGRATED-APPROACH-ebook-ISBN.pdf

[5] Donnelly, R., Dallat, J., \& Fitzmaurice, M. (Eds.). (2013). Supervising and writing a good undergraduate dissertation. Bentham Science. Retrieved from https://books.google.com.mx/books

[6] Gomez, J. C. (2014). The development of writing skills in master's level English as a foreign language teacher education programs: insight into the process and perceptions from stakeholders in Colombian universities. [Unpublished Doctoral dissertation]. University of Alabama. Retrieved from https://ir.ua.edu/bitstream/handle/123456789/2017/file 1.pdf?sequenc $\underline{\mathrm{e}=1 \& \text { is Allowed }=\mathrm{y}}$

[7] Griffee, D.T. (2012). An introduction to second language research methods: design and data. USA. Retrieved from http://www.teslej.org/pdf/ej60/sl_research_methods.pdf

[8] Ho, M. C. (2013). The difficulties in disciplinary research writing: A case study of first-year graduate students in Taiwan. Journal of 
Teaching and Education, 2(4). 77-87. http://www.universitypublications.net/jte/0204/pdf/M3K67.pdf

[9] Komba, S. C. (2015). Challenges of writing theses and dissertations among postgraduate students in Tanzanian higher learning institutions. International Journal of Research Studies in Education, 5(3), 71-80, https://doi.org/10.5861/ijrse.2015.1280

[10] Mackey, A. \& Gass, S. M. (2005). Second language research: Methodology and design. Lawrence Erlbaum Associates Publishers. Retrieved from https://www.manaraa.com/upload/8be2a1cf-62754941-971c-ae6446630635.pdf

[11] Mauch, J.E., \& Park, N. (2003). Guide to the Successful Thesis and Dissertation: A handbook for students and faculty. New York: M. Dekker, Boulder. $\quad$ Retrieved from http://citeseerx.ist.psu.edu/viewdoc/download?doi=10.1.1.463.265\&re $\mathrm{p}=\mathrm{rep} 1 \&$ type $=\mathrm{pdf}$

[12] Moreno, M. E., \& Domínguez, A.M. (2007), La investigación sobre la enseñanza de lenguas extranjeras en la Universidad Autónoma de Chiapas. In J.L., Ramírez (coord.), Las investigaciones sobre la enseñanza y el aprendizaje de lenguas extranjeras en México. pp. 6468. México: Plaza y Valdés.

[13] Paltridge, B. (2002). Thesis and dissertation writing: an examination of published advice and actual practice. English for Specific Purposes, (21), 125-143. Retrieved from https://doi.org/10.1016/S08894906(00)00025-9

[14] Paltridge, B. \& Starfield, S. (2007). Thesis and dissertation writing in a second language: a handbook for supervisors https://www.ccsu.edu/EdDwritingInstitute/facultyResources/files/thesi s_writing.pdf

[15] Paltridge, B. (2013). Genre and english for specific purposes. In B Paltridge \& S. Starfield (Authors), The handbook of English for specific purposes (1st ed., pp. 347-366). Chichester, West Sussex: Wiley Blackwell. https://doi.org/10.1002/9781118339855.ch27.

[16] Peng, H. (2018). Supervisors' views of the generic difficulties in thesis/dissertation writing of Chinese EFL research students. The Asian Journal of Applied Linguistics, 5(1), 93-103. Retrieved from https://caes.hku.hk/ajal/index.php/ajal/article/view/524/528

[17] Ramírez, J. L. (Coord.) (2007). Las investigaciones sobre la enseñanza y el aprendizaje de lenguas extranjeras en México. México: Plaza y Valdés.

[18] Shaw, P. (1991). Science research students' composing processes. English for Specific Purposes, 10(3), 189-206. https://doi.org/10.1016/0889-4906(91)90024-Q

[19] Singh, M. (2015). International Graduate Students' Academic Writing Practices in Malaysia: Challenges and Solutions. Journal of International Students, 5(1), 12-22. Retrieved July 20, 2020, from https://www.ojed.org/index.php/jis/article/view/439

[20] Stake, R. (1995). The Art of Case Study Research. Thousand Oaks, CA: SAGE. Retrieved from https://books.google.com.mx/books?id=ApGdBx76b9kC\&printsec=fr ontcover\&dq=Stake, + R. $+(1995) .+$ The + Art+of + Case + Study + Researc $\underline{\text { h. }}$

[21] Stanford (n.d). Dissertation reading committee. Retrieved in 2020 from https://ed.stanford.edu/academics/doctoralhandbook/milestones/dissertation-committee

[22] Tan, F. \& Hunter, M. (2002). The repertory grid technique: A method for the study of cognition in information systems. MIS Quarterly, 26(1), 39-57. https://doi.org/10.2307/4132340.
[23] Tapia, R. (2013). Pre-service teachers' beliefs about the roles of thesis. Gist Education and Learning Research Journal, 7, 74-92. Retrieved January 17, 2020, from https://dialnet.unirioja.es/servlet/articulo?codigo $=4709228$

[24] Tardy, C. M., \& Swales, J. M. (2009). Form, text organization, genre, coherence, and cohesion. In Handbook of Research on Writing: History, Society, School, Individual, Text (pp. 693-714). Taylor and Francis. Retrieved from https://doi.org/10.4324/9781410616470-47

[25] Thompson, P. (2013). Thesis and dissertation writing. In B. Paltridge \& S. Starfield (Authors), The handbook of English for specific purposes (1st ed., pp. 283-299). Chichester, West Sussex: Wiley Blackwell. https://doi.org/10.1002/9781118339855

[26] Universidad Autónoma de Chiapas. (2018, August 7). Modalidades de titulación a egresados. Retrieved April 24, 2020, from https://www.elt.unach.mx/index.php/30-inicio

[27] Wang, C. (2016). A comparative genre analysis of schematic structures in public speeches of native and nonnative English speakers. Linguistics and Literature Studies, 4(5), 320-330. https://doi.org/10.13189/1ls.2016.040502

[28] Woods, A., Fletcher, P. \& Hughes, A. (1986). Statistics in language studies. Cambridge: Cambridge University Press. https://books.google.com.mx/books?id=MDhZpf7C7IMC\&printsec=f rontcovughes,+A.+(1986).nguage+studies.+Cambridge:+Cambridge+ University+Press

[29] Yeh, C. (2010). New graduate students' perspectives on research writing in English: A case study in Taiwan. Journal of Academic Language and Learning, 4(1). A-1-A12. Retrieved June 16, 2020 from https://journal.aall.org.au/index.php/jall/article/view/115/83 